\title{
Las constituciones sinodales y la imagen procesional. Normas para la fiesta del siglo XVI
}

\author{
Palma martínez-Burgos García \\ "... no queramos reunir a Dios con \\ unas ceremonias mágicas, o que \\ parecen hechizerías, como harian \\ los judios..."
}

Erasmo de Rotterdam

Cuando Erasmo de Rotterdam afirma que las ceremonias «son todas buenas en la medida que expresan una piedad íntima", está denunciando uno de los aspectos más controvertidos de la religión católica. Una religión que se define por su culto externo, en la que procesiones, peregrinaciones, veneración de santos, de sus imágenes y reliquias, no sólo están arraigadas en la mente popular sino que, además, forman una creencia indivisible en su conjunto. Las ideas del humanista holandés acerca de la imagen, de las reliquias, de las ceremonias y del clero, por muy radicales que a veces parecieran, se mantuvieron siempre dentro de los límites de la ortodoxia católica, lo que no impidió que, a raíz de ellas, la Iglesia comience a elaborar un corpus ideológico para legitimar el uso de la imagen y la validez de las ceremonias. En cuanto a la primera queda institucionalizada al reconocerla como la "Biblia pauperum", y res- 
pecto a las ceremonias se llegará a afirmar que fue el propio Jesucristo quien instituyó su valor devocional a partir de su vida y obras. ".

Para su defensa la Iglesia cuenta, entre otros, con un medio importante y eficaz: el papel de los obispos en rehabilitar unas prácticas desprestigiadas es esencial. Por ello lo que nos interesa destacar no es tanto su función supervisora, como la acción "legislativa" que ejercen a través de los sínodos que convocan y que conocemos por medio de las constituciones sinodales.

Éstas se convierten en el gran soporte con que cuenta la ortodoxia católica de cara al contacto diario con el fiel. A través de ellas no sólo se refuerza la teoría eclesiástica sino que, algo más interesante en aquellos momentos, se desarrolla una labor de autocrítica inculcada por el espíritu de la Reforma de Cisneros y que culmina con el Concilio de Trento.

Como documento, las constituciones sinodales poseen un patente carácter reiterativo ya que manejan y repiten argumentos encaminados a fortalecer el valor catequístico y devocional de las ceremonias; los mismos argumentos que, años más tarde, sistematizará y recogerá el Concilio de Trento en su breve sesión dedicada a imágenes ${ }^{2}$. De esta forma, durante toda la centuria se promueve una religión básicamente emocional, como ya es sabido, pero también fuertemente regulada, si bien las manifestaciones que caracterizan la cultura visual que se va imponiendo, escapen y marginen las reglas que se esconden detrás provocando en muchas ocasiones fuertes y dudosas contradicciones entre la práctica y la teoría.

En este contexto, la procesión, como elemento canalizador de la fiesta religiosa, se convierte en un vehículo especialmente didáctico y propagandista que polariza, desde los primeros años de la centuria, un interés constante por parte de los obispos. La constitución sinodal de Toledo de 1536, ordenada por el Cardenal Tavera, establece claramente cuáles son los fines que con ella se persiguen «... Las procesiones

- Asi es tal y como lo recoge Giuseppe Scavizzi en Arte e Architettura sacra. Cronache e documenti sulla controversia tra riformati e cattolici 1500-1550. Roma. Casa del Libro Editrice, 1981.

En cuanto a la teoria erasmista, ver Erasmo DE RotTERDAM, Enchiridion o manual del caballero cristiano. Madrid, Ed. de Dámaso Alonso CSIC, 1971. La misma critica la aborda en los Coloquios, Madrid, NBAE, 1915. "Coloquio V, el cual llaman de religiosos".

2 Ver Ignacio LOPEZ DE AYALA, El sacrosanto y ecuménico concilio de Trento. Madrid, Imprenta Real, 1875. Sesión XXV «De la invocación, veneración y reliquias de los santos, $y$ de las sagradas imágenes». 
fueron ordenadas para provocar a los cristianos la devoción, y porque nuestro Señor mejor oyere las oraciones y plegarias del pueblo que en ellas se ajunta...” ${ }^{3}$.

El hecho de que sea a través de un código puramente visual como se inculca la autoridad de la iglesia, y de que la procesión sea, dentro de ese código, un poderoso instrumento, hace que se dedique una especial atención y cuidado a los aspectos más ornamentales con los que se muestra la fiesta religiosa. Es decir, se proyectan todo tipo de advertencias en torno al boato $y$ atavío tanto del templo, como del medio urbano en el que se desarrolla, sin olvidar la particular vigilancia que se presta a las imágenes procesionales 0 , también llamadas, «de vestir».

En cuanto al adorno del templo se advierte el afán de que éste se convierta en un trasunto fiel del paraíso, intentando mantener el simbolismo tradicional de la iglesia que hacía de ella la viva imagen de la Jerusalen celestial. Con esta corriente de pensamiento enlaza Fray Hernando de Talavera quien, al publicar en 1496 su Breve y muy provechosa doctrina de lo que debe saber todo cristiano ${ }^{4}$, se erige en el precedente más inmediato de lo que, a lo largo del siglo XVI, persiguen muchas constituciones sinodales que tratan del aderezo, entre las que cabe destacar las del Obispado de Osma, celebradas en 1548 y convocadas por el obispo Sebastián Pérez. En ellas se recomienda que para el Jueves santo “... se hagan teñir negros algunos lienzos gruesos, los cuales se pueden colgar en la capilla del Monumento, pintando en ellos la cruz, o algún paso de la pasión...» ${ }^{5}$, con el fin de que todo el templo transmita la misma imagen que al fiel le llega por el sermón.

Por semejantes motivos, se insiste en que no se presten los ornamentos de las iglesias, criticando la costumbre que existía de intercambiar objetos con motivo de fiestas y solemnidades, por lo que en la constitución sinodal de Palencia de 1548 se prohíbe que se «...empresten ornamentos, joyas y atavíos, ni otras cosas preciosas que son de las

3 Constituciones synodales del Arçobispado de Toledo: hechas por el llmo. don Juan Tavera, cardenal... Arçobispo de Toledo. Al fin: Alcalá de Henares. En casa de Miguel de Eguía 1536, fol. IX.

4 Fray Hernando oe talavera, Breve y muy provechosa doctrina de lo que deve saber todo christiano con dos tratados muy provechosos. Granada, 1496. Ver en concreto el "Tratado de lo que significan las ceremonias de la missa", en el que explica el significado de cada ornamento que se aloja en el templo.

5 Constituciones Synodales del Obispado de Osma, ordenadas por el Rdmo. señor D. Sebastián Pérez, Obispo de dicho obispado. A 3 de julio de 1548. Con licencia, impresas en su villa del Burgo, por Diego Fernandez de Cordoba. Año de 1586, fol XXXII. 
iglesias... para bautismos, mortuorios ni otros usos profanos", y sólo se permite el intercambio cuando es dentro de una misma localidad ${ }^{6}$. Contraviniendo este tipo de recomendaciones sabemos, por la crónica que escribe Cianca a la llegada de las reliquias de San Segundo a Ávila, que "...la iglesia de Ávila escribió a la de Toledo pidiéndola algunos de sus ricos aderezos...", lo que hace sospechar que se trataba de una práctica habitual ${ }^{7}$.

Mucho más importante era, sin embargo, el que los objetos destinados al adorno del templo fueran decentes y honestos. La recomendación la encontramos nuevamente en la constitución sinodal de Osma cuando se especifica que «...no se cuelguen tapices de historias que inciten a pecado o deshonestidad, ni lieços ni otras pinturas de esta manera...". Estas palabras y semejantes se mantienen, a modo de consigna, en todos los documentos sinodales que abordan el tema de la fiesta. En Sevilla y en los primeros años del siglo XVII, 1604, se sigue recomendando que se aderece todo con la mayor decencia y autoridad que conviene a tan grande lugar y que si se hubiere de poner cuadros, estos sean de santos «o de cosa de devoción - se dice literalmente- i prohibimos que en ninguna manera se pongan retratos de infieles, ni pinturas deshonestas" 8 .

La medida, que se hace extensible también al adorno de las calles, parece ser un intento por frenar el desarrollo de los elementos mitológicos que empezaban a aparecer con excesiva frecuencia en el adorno de las calles, como reflejo de la progresiva modernización del gusto que va imponiendo los modelos "a lo antiguo". Quien fundamentalmente aportaba las historias mitológicas era la nobleza, que contribuía de esta forma al adorno cediendo también sus blasones y escudos. A pesar de la con-

- Constituciones Synodales del Obispado de Palencia ordenadas por mandato del ilustre y rdmo. D. Luis Cabeça de Vaca, obispo de dicho obispado. Año de 1548, fol. XLI.

A. DE CIANCA, Historia de la vida, invención, milagros y traslación de San Segundo, primero obispo de Ávila. En Madrid, por Luis Sánchez. Año de 1595.

Un dato que nos hace ver la cotidianeidad de esta clase de préstamos es que, ya en el XVII y en Segovia, se sigue diciendo "...que no se presten las joyas y ornamentos de las iglesias". Ver el "Sínodo diocesano que celebró el llmo. y Rmo. Sr. don frai Francisco de Araujo, obispo de Segovia". Año de 1648, Segovia, imprenta de D. Eduardo Baeza, 1847, pág. 157.

8 Constituciones del Arzobispado de Sevilla hechas y ordenadas por el limo. y Rdmo. Señor D. Francisco Niño de Guevara, cardenal y arzobispo de la Santa Iglesia de Sevilla. Año de 1604. Y mandadas imprimir en Sevilla, año de 1609, por Alonso Rodriguez Gamarra. Cap. IX "De la suerte y manera que se han de aderezar los templos para las fiestas y las calles para las procesiones». 
tradicción que esto implica, era habitual que fuera la propia Iglesia la que se dirigiera a los estamentos nobles con el fin de que cediesen sus tapicerías, colgaduras y telas para el aparato de las traslaciones y ornato de la ciudad. Por ello es frecuente a lo largo de la procesión del siglo XVI, ver desfilar imágenes y pinturas de temas devotos junto a los arcos triunfales con las representaciones de los trabajos de Hércules, los hechos de Sansón y la toma de ciudades al Turco, sin olvidar la masiva presencia de un lenguaje emblemático cada vez más complejo y elaborado. Tal es lo que se lee en las crónicas de las fiestas de Toledo cuando llega la reliquia de San Eugenio o la de Santa Leocadia; en Ávila al recibir a San Segundo, o en Lisboa a la entrada de un envio de santas reliquias ${ }^{9}$.

La ciudad amanecia entonces con sedas, telas y brocados que tapizaban edificios enteros; se cerraban plazas y se colocaban arquitecturas efímeras en un intento por sacralizar todo el marco en el que se desarrolla la procesión. Es el espacio urbano el que sufre una auténtica transformación, hasta convertirse en un gran escenario del que se intenta que queden desterrados aquellos rasgos más paganos que la fiesta religiosa renacentista ha heredado de la mentalidad medieval. Las criticas a las representaciones, farsas, chanzas, obras de teatro o de titeres, sobre asuntos religiosos, son fiel reflejo de una preocupación que va más allá de los límites de la moral, y, ya durante el reinado de Carlos V, las constituciones sinodales insisten en acabar con este aspecto carnavalesco de la fiesta religiosa. El Sínodo de Córdoba, celebrado en 1521, incluye un capítulo «...sobre que en las iglesias no se hagan representaciones de los misterios de la Natividad, Pasión y Resurrección de Cristo" ya que "provocan más al pueblo a dirisión de la tal fiesta y solemnidad" y acaba reprobando la costumbre que se tiene de hacer actos so color de piedad, en los que "en lugar de las bendiciones de las lictiones de maitines se lo pasan diciendo deshonestidades y cantando cantares torpes $y$ feos $y$ faciento otras cosas feas..." ${ }^{10}$.

El libro del Padre Mariana, Tratado contra los juegos públicos, ha quedado como el paradigma de una mentalidad que intenta potenciar una religión más propagandistica y devocional si bien, el mismo rechazo e

\footnotetext{
9 En Ávila, por ejemplo, sabemos que la Ciudad y la Iglesia escriben a los grandes "...suplicando diessen de sus tapicerías y colgaduras de brocado y telas para el aparato de la traslación y ornato de la ciudad". A. DE CIANCA; obra citada, Cap. XV.

10 Constituciones Synodales del Obispado de Córdoba. Al fin: Sevilia. Por Jacobo Cromberger. Año de 1521. Título XII, cap. I. Fol. XLIII, "Que en las iglesias no se hagan representaciones".
} 
indignación se sigue advirtiendo en otras muchas constituciones sinodales ${ }^{11}$.

De este modo la procesión queda asociada a sucesos que reflejan una ideología contrarreformista y, en definitiva, se deja sentir la impronta de Felipe II, al potenciar una festividad religiosa dirigida a favorecer el culto debido a santos y reliquias. Mientras que las procesiones que presencia el hombre renacentista mantienen el sabor carnavalesco, popular y transgresor que revela Mijail Batjin en su estudio acerca de la cultura popular en la Edad Media y el Renacimiento, el objetivo de las que invaden las ciudades bajo el reinado del sucesor de Carlos $\mathrm{V}$, es el de "servir de ejemplo a los de este reino y, sobre todo, de confusión a los herejes" como se manifiesta en algunas de las crónicas de traslaciones de reliquias que hemos citado anteriormente ${ }^{12}$.

En ellas se advierte también un auténtico entusiasmo popular por participar en los preparativos, cada vez más complejos, de una festividad que comporta ese carácter ejemplar y devocional ya señalado. Tanto las relaciones sobre fiestas como los documentos sinodales, prestan una minuciosa atención a los detalles más insignificantes, al tiempo que intentan regular la entusiasta colaboración del pueblo, colaboración canalizada a través de gremios, cofradías y hermandades sacramentales. La presencia e importancia de estos grupos en la procesión del xvı sería, por si sólo, objeto de un estudio aparte por la fuerza social que adquieren en ella. Lo que aquí queremos destacar precisamente son los problemas que provocan estos grupos debido al auge que toman y a la competencia existente entre ellos. Las rivalidades por lucir aparatos e invenciones cada vez más ricos, originan costes sumamente elevados. El problema económico quedará sin embargo resuelto por la intervención de la iglesia y el cabildo en cada caso; por eso, casi más importante eran los numerosos altercados que solian producirse en tales ocasiones. No es de extrañar que en muchas crónicas se den gracias a Dios porque a pesar «del alboroto, confusión y gentio, y a pesar de que hay entre los cofrades

11 Las de Mondoñedo en 1541, Granada en 1572, Cartagena en 1583, Navarra en 1590 y Orihuela en 1600 , continúan insistiendo, en un tono cada vez más enérgico, en que se ha de acabar con algo que conduce más a la burla que a la devoción.

12 Efectivamente, tanto Sebastián Horozco, Solemne entrada y triunfo de las reliquias de San Eugenio de Toledo. Ms. de la Biblioteca Nacional, como A. DE CIANCA, obra citada, insisten en que estas ceremonias renuevan la memoria y devoción del santo y, sobre todo, con ellas se alecciona al protestante. El carácter opuesto lo encontramos en el interesante análisis de Mijail BatJIN, La cultura popular en la Edad Media y el Renacimiento. (El contexto de François Rabelais). Barcelona 1974. 
grandes enojos y pasiones sobre los lugares y antiguedades, aquel día todo fue amor y concordia y todos fueron con grande devoción...", como nos revela Sebastián Horozco en la Relación de la entrada de las reliquias de San Eugenio en Toledo. También en las constituciones sinodales se amonesta a los feligreses para que desfilen sin disturbios, se guarde silencio, se prohibe ir a caballo y se recomienda que los hombres vayan detrás sin mezclarse con las mujeres; las de Toledo de 1536, son de las primeras que abordan este aspecto ${ }^{13}$.

De todos los puntos que se vienen tratando en torno a la fiesta religiosa, es el de la licitud de la imagen el que más atención despertó. En el debate se mide por igual el profundo arraigo popular con que contaba este culto con los esfuerzos, por parte de las autoridades eclesiásticas, en moderarlo y canalizarlo. En el enfrentamiento, meramente teórico, la devoción hacia las imágenes de vestir sale fortalecida, y la Iglesia no tiene más remedio que mantener sus constantes censuras casi por pura rutina, aunque el tono sea cada vez de mayor indignación.

El desarrollo de estas imágenes está vinculado al que experimenta la propia procesión siendo ésta su destino fundamental, donde cofradias, pueblo llano y nobleza compiten en aderezarlas, cayendo en la ostentación desmesurada, y a todas luces inconveniente, que se intenta frenar. En las amonestaciones a las vestimentas subyace la labor crítica que Cisneros ejerció sobre el lujo que algunos eclesiásticos mostraban en su atavío. Sin embargo, de cara a la imagen procesional lo que se quiere evitar es esa cotidianeidad excesiva en la que caían las imágenes sagradas al revestirlas de unos vestidos, posturas y aderezos que recordaban demasiado a modas concretas, haciendo peligrar la línea divisoria entre lo divino y lo meramente terrenal ${ }^{14}$.

En cuanto al contenido mismo de las constituciones sinodales que abordan este tema, y que se dan masivamente a partir del Concilio de

13 Pero no las únicas y prácticamente a lo largo del xVI, se sigue vigilando esta faceta de la procesión. Finalmente en el XVII, se acude a la fórmula de cque no salga ninguna cofradía, ni hermandad sin tener primero señalado el lugar donde hubiere de ir, y licencia nuestra o de nuestro Provisor", según lo expresa fa Constitución de Segovia de 1648, ya citada.

14 San Juan de la Cruz denuncia el ornato y atavio de las imágenes por las contradicciones en que se incurría en la mayoría de las veces. Véase San Juan DE LA CRUZ, La subida al Monte Carmelo. La Plata, 1944. Cap. XXXV.

También MARTIN DE AZPILCUETA opina que muchos de los atavíos con que se recubre a la Virgen o a la Magdalena son propios más de meretrices que de santas mujeres. Ver su Comento en romance a manera de repetición latina y scholastica... En el qual se trata de la oración, horas canónicas y otros oficios divinos. Coimbra 1545, cap. V. 
Trento, se advierten dos aspectos que se censuran en nombre de una moral ya característica de la Contrarreforma.

El primero sobre el que se alecciona e insiste concienzudamente es el de no manipular las imágenes sagradas, ni en su atavio ni con fines encaminados a fomentar supersticiones. El segundo, mucho más grave, es el que acabamos de aludir: el peligro que suponía vestir y aderezar unas imágenes de tal forma que se violaban las más mínimas normas de decoro y honestidad, términos éstos que nos sitúan de lleno en la mentalidad contrarreformista. Con todo ello lo que se intenta es que la imagen resulte conveniente, es decir, honesta y decente $y$, en definitiva, que no provoque malos pensamientos ni tuerza los ánimos. $Y$ aquí es donde entramos en el aspecto edificante, moralmente hablando, que cobra el decoro referido a la imagen sagrada concebida como "biblia de los pobres".

En la polémica que mantienen los arzobispos no se censuran tanto las imágenes en sí mismas, como la visión que de ellas tengan los demás. La idea de que vaya ataviada con decoro y honestidad de tal forma que no degenere en mal lo que se instituyó con buen fin, se repite, a manera de fórmula, en todos los documentos sinodales del XVI y masivamente en las últimas décadas de la centuria. Nuevamente volvemos a las promulgadas en Toledo en 1536 por el Cardenal Tavera, ya que son de las primeras que inician esta serie de recomendaciones. Alli se establece que: «...las imágenes que hallaren que no estén honesta o decentemente ataviadas, especialmente en los altares, 0 las que sacan en procesiones, las hagan poner decentemente, y donde hallaren aparejo para ello procuren de las mandar hacer todas de bulto, para que puedan estar sin ponerles otras vestiduras" ${ }^{15}$.

A las de Toledo le siguen otras muchas repartidas por toda la península, sobre todo en el sur donde este culto contaba con gran arraigo, si bien se refleja una importante intensificación desde los años sesenta en adelante. Las de Santiago de Compostela en 1565, Cuenca en 1571, Cartagena en 1583, Segovia en 1586, Pamplona en 1590, Valencia en 1594 , amén de otras muchas, que sería prolijo e innecesario citar, manejan todas el concepto de decoro como baluarte de la moral contrarreformista ${ }^{16}$.

15 Constituciones Synodales del Arzobispado de Toledo... fol. V.

16 En Ciudad Rodrigo, por ejemplo, se impone una multa de cuatro ducados a cada cura o beneficiado que tenga o consienta tener imagen de talia o vestida "...que no este 
Lo que molesta a los vigilantes de la nueva moral no es, por lo tanto, la devoción que se tiene a las imágenes de vestir sino el que éstas se recubran de aderezos, tales como joyas, pelucas y vestidos, prestados y donados por mujeres nobles en la mayoría de los casos; por lo que se exige que, de llevar trajes, éstos sean propios y hechos para ellas de forma exprofesa. Desde que en 1565 se declara en el Sínodo de Compostela que los vestidos y velos muestren sólo aquellos adornos que hayan sido previamente aprobados por el obispo o su vicario, las advertencias, recomendaciones y amenazas se multiplican, no existiendo sínodo que no incluya anotaciones a este aspecto, Cartagena en 1583 declara abiertamente la impropiedad de que haya en la Casa del Señor cosa que no pertenezca a religión, por lo que se dice, «...ordenamos y mandamos que las imágenes de bulto... las hagan adereçar los dichos visitadores y vicarios de propias vestiduras para aquel efecto hechas decentemente, las cuales no puedan servir más a mujeres, ni para otros usos profanos..." "?.

Copetes, rizos, arandelas, encajes y pelucas daban el aspecto más folklorista a las imágenes que desfilaban en las procesiones, y que denuncia con cierta amargura el obispo de Orihuela en el sínodo de 1600: “... Hay que dolerse de que en las iglesias, mientras se celebran procesiones... las imágenes de los santos sean adornadas con una belleza tan desvergonzada y un esplendor tan mundano... con tanto adorno y tocados de mujer, con vestidos de seda, según la costumbre de las mujeres profanas, que induzcan los ánimos de los espectadores, no a la piedad, sino a la lascivia y a la lujuria. Por lo cual mandamos que desde ahora no sean vestidas de ese modo las imágenes... con vestidos recibidos en préstamos de mujeres profanas, ni aliñadas con hábito secular..." ${ }^{18}$.

Por la divinidad que representan las imágenes se considera irrespetuoso ese intercambio de vestiduras e, igualmente, la manipulación a la que antes nos referíamos, máxime cuando "...acaesce muchas veces que para vestir y componer las dichas imágenes, los sacristanes e mu-

con la decencia y ornato que representa y conviene".

Constituciones Synodales del Obispado de Ciudad Rodrigo. Hechas y ordenadas por D. Martín de Salvatierra, obispo de dicho obispado. En abril de 1592. Salamanca 1595. Libro III, cap. I.

17 Constituciones Synodales del Obispado de Carthagena, por D. Hyeronymo Manrique de Lara, obispo de Carthagena. Año de 1583. En Valladlid por Andrés MeRCHAN y Claudio BoLAN, año de 1590. Cap. II, fol. XXXI.

${ }_{18}$ Sinodo Diocesano de Orihuela. Año de 1600 . Sesión $1 .^{a}$, cap. XIV, pág. 139. En Crescenciano SARAVIA, Repercusión en España del decreto del Concilio de Trento sobre imágenes. BSAA. Valladolid, Tomo XXVI. 1960. 
jeres que las componen, subirse de pie a los altares y tratar irreverentemente las cosas sagradas", como se dice en la constitución sinodal de Segovia de $1586{ }^{19}$. En muchas se lee la prohibición de que sean las mujeres quienes las vistan, dejando a los sacristanes esta labor; también se insiste en que, bajo ningún concepto, se saquen de las iglesias, y aquellas que sean propiedad de las cofradias deberán ser restituidas a su lugar de origen después de la procesión. Con esta medida se pretende acabar con una serie de prácticas supersticiosas, en las que la imagen desfilaba por campos y cultivos, e incluso se la sumergía en los ríos, con el fin de favorecer cosechas, atraer las lluvias y otra serie de peticiones igualmente interesadas "...y porque hay otras muchas supersticiones en nuestro obispado, mandamos a los curas no permitan abusar de ellas" se acaba diciendo en la constitución sinodal de Burgo de Osma publicada en $1586^{20}$.

En todos los documentos eclesiásticos que venimos analizando se deduce que para terminar con los abusos denunciados, lo mejor es hacerlas "todas de bulto", como ya se adelantaba en el sínodo de 1536 celebrado en Toledo. Las implicaciones que esta recomendación tuvo sobre el quehacer artístico son contradictorias ya que, si por un lado se potenció una labor imaginera y escultórica cada vez más perfeccionada, por otro, sabido es que no se logró remediar los errores que se siguieron cometiendo, a pesar de la vigilancia de los veedores y obispos, a pesar de la prohibición de tener esas imágenes en público y en privado y a pesar de la labor de los entalladores y pintores ${ }^{21}$.

Por otra parte, aunque en las constituciones de los sínodos celebrados a lo largo del XVI, se plasma un auténtico esfuerzo por regular y canalizar el sentimiento religioso, se puede afirmar que ese sentimiento desbordó todo intento normalizador, y que asistimos a una religiosidad vivida de forma desbordada y exhuberante y, a veces supersticiosa, que se volcaba sobre todo con motivo de la festividad religiosa.

19 Constituciones Synodales del Obispado de Segovia, hechas por D. Andrés de Cabrera. En el año de 1586. Impresas en Barcelona en casa de Hubert Gotard en el año de 1587.

${ }_{20}$ Constituciones Synodales del Obispado de Osma... obra citada. Además de las mencionadas de Méjico y Valencia, destacamos las de Cuenca de 1571 y Granada de 1572 , indicándose en todas ellas el malestar y los errores que esas prácticas supersticiosas suponían.

${ }_{21}$ Aún así, en 1642, la Iglesia prohíbe radicalmente mostrarlas y poseerlas para que "...las fieles no se viesen perturbados en su devoción ante la vista de cosas tan desacostumbradas e insólitas", ver Rodriguez G. DE Ceballos, "La repercusión en España del decreto del Concilio de Trento acerca de las imágenes sagradas y las censuras al Greco", Studes in the History of Art, vol. XIII, 1984, pág. 153-158. 
De todos los aspectos teóricos que tocan este tipo de documentos respecto a la fiesta, sólo nos hemos querido detener en aquellos que implican la acción de una espiritualidad más popular haciendo desplegar una vigilancia constante con advertencias que, por lo reiterativo, demostraban tener poca eficacia.

El peso de esa vigilancia recae sobre la figura del obispo que sale fortalecida después del Concilio de Trento al convertirse en el veedor, no sólo de buenas costumbres, sino más importante de cara a lo que aquí tratamos, de todos los objetos artísticos que albergaba la diócesis, entre los cuales las imágenes despertaban un poderoso atractivo. En cuanto a la fiesta religiosa, su presencia es decisiva a la hora de comprender el papel catequístico, devocional y combativo que adquiere la procesión, tal como lo demuestran las que tuvieron lugar en numerosas ciudades de España -con motivo del traslado de reliquias y de recibimientos a personajes ilustres-, las crónicas que las relatan y las fuentes sinodales que las controlan ${ }^{22}$.

Dentro de este panorama cabe decir que a pesar de la labor inquisitorial que desarrollan los obispos, esa labor queda muchas veces en un nivel puramente teórico, ya que en la realidad la propia Iglesia favorece muchas prácticas que estaban siendo condenadas, sabedora de que era imposible erradicar el aspecto más atractivo y útil, devocionalmente hablando, como era la vertiente ceremoniática y ritual que caracteriza a la religión católica. El reconocimiento de que no era ni siquiera conveniente aplicar las estrictas normas contrarreformistas a la imagen les hace caer en constantes contradicciones. La cuestión de las imágenes de vestir es sólo un ejemplo de esa paradoja en la que incurre la Iglesia, quien se debate entre la inutilidad de la censura y la fuerte atracción que ejercen.

A la luz de las fuentes sinodales se percibe, por último, que existe un espiritu reformista, combativo y militante, de tal forma que todo 10 referente a imágenes, santos y reliquias tratado en la sesión XXV del Concilio de Trento llevaba ya años circulando dentro del territorio español; en este sentido Trento no hace sino reafirmar y recoger sistemáticamente unas ideas que estaban siendo promulgadas por nuestros

22 Efectivamente, en la mayoría de las relaciones sobre fiestas se enumera detalladamente el nombre, número y boato con que desfilan los arzobispos que acuden desde las comarcas vecinas al lugar señalado. En Toledo, con motivo de la llegada de San Eugenio, están presentes el obispo de Córdoba, el de Segovia, el de Palencia y el de Cuenca, precedidos, naturalmente, por el de la diócesis titular. 
arzobispos desde los primeros años del siglo. La actitud de estas autoridades eclesiásticas nos lleva a afirmar que durante el XVI se dan una serie de "contrarreformas", la primera de las cuales sería la encabezada por el Cardenal Cisneros, alcanzando la máxima pureza la dirigida por Felipe II, sin olvidar la presencia de obispos contrarreformistas Juan Tavera, Juan Martínez Silíceo, ambos arzobispos de Toledo, y el beato Juan de Ribera, arzobispo de Valencia y fundador del colegio del Corpus Christi, son algunos nombres ${ }^{23}$.

$\mathrm{Si}$ admitimos tal hipótesis, estaríamos ante una religiosidad que se distinguiria por su militancia, pero que no olvida las profundas raíces que tiene en una sociedad caracterizada por su pluralismo y "heterodoxia", y que se manifiesta plenamente dentro del marco festivo que le proporciona la procesión.

23 Todos se distinguen por su labor de mecenazgo en torno a fundaciones de colegios, hospitales y demás, como principal manifestación de su carácter propagandista. Al mismo tiempo muchos de ellos se convierten en foco importante de captación de artistas. Véase el ejemplo del Beato Juan de Ribera y Luis de Morales. 